\title{
Simultaneous Monitoring of Filter Ventilation and a Gaseous Component in Whole Cigarette Smoke Using Tunable Diode Laser Infrared Spectroscopy*
}

\author{
by Milton E. Parrish, Charles $N$. Harward and Gunars Vilcins
}

Pbilip Morris Research Center, Richmond, Virginia, U.S.A.

\section{SUMMARY}

A computer-controlled high-resolution infrared tunable diode laser (TDL) system has been developed to determine simultaneously the concentration of a gaseous smoke component (carbon monoxide) and the filter ventilation of a cigarette during smoking. The simultaneous monitoring of these two parameters provided information which can lead to enhancing the successful development of new cigarette products.

The approach selected was to place a cigarette with the ventilation holes of the filter in a chamber filled with a gas not normally detected in cigarette smoke, such as nitrous oxide $\left(\mathrm{N}_{2} \mathrm{O}\right)$, and to mix this gas with the smoke under actual smoking conditions. The $\mathrm{N}_{2} \mathrm{O}$ provided information concerning the ventilation level and the representative smoke component provided information about the mainstream smoke delivery. This is the first study of which we are aware where the concentration of a smoke component was obtained simultaneously with the dynamic ventilation level within seconds after each puff was taken.

Experiments were conducted with cigarettes having different filter ventilation levels $(0 \%, 13 \%, 30 \%, 40 \%$, $60 \%, 75 \%$ and $90 \%$ ). Each cigarette was measured for the static ventilation prior to smoking using the CORESTA standard ventilation method. These values were in good agreement with those obtained using the TDL.

The data collected during this study confirmed that the concentration of the mainstream component investigated increased as the filter ventilation decreased from $90 \%$ to $0 \%$. With respect to puff number, the ventila-

\footnotetext{
* Received: 6th March 1985 - accepted: 18th December 1985.

Presented, in part, at the 8th International Tobacco Scientific Congress (Conests) beld in Vienna, Austria, in 1984.
}

tion increased slightly during the first puffs then decreased for the later puffs, while the delivery of the smoke component monitored increased with increasing puff number. The $40 \%$ ventilation cigarette showed the largest change in ventilation during smoking compared with the value for the unlit puff.

\section{ZUSAMMENFASSUNG}

Die Autoren entwickelten ein rechnergestūtztes, abstimmbares, hochauflōsendes infrarotspektrographisches Diodenlaserverfahren (TDL), um die Konzentration einer gasförmigen Rauchkomponente (Kohlenmonoxid) einerseits und die Filterventilation einer Zigarette andererseits während des Abrauchvorganges gleichzeitig zu messen. Die Ergebnisse der gleichzeitigen Bestimmung der beiden genannten Parameter könnten die Entwicklung neuartiger Zigaretten günstig beeinflussen.

Die Zigarette ist in der Versuchsanordnung so positioniert, daß die Ventilationsöffnungen des Filters sich in einer Kammer befinden, die mit einem normalerweise im Rauch nicht vorhandenen Gas wie beispielsweise Distickstoffoxid $\left(\mathrm{N}_{2} \mathrm{O}\right)$ gefüllt ist, das unter den üblichen Abrauchbedingungen mit Zigarettenrauch gemischt wird. Während das Distickstoffoxid Informationen über die Ventilation vermittelt, gibt der Rauchinhaltsstoff reprāsentativ Auskunft über die Ausbeute im Hauptstromrauch. Auf diese Weise wurde nach Kenntnis der Autoren zum erstenmal innerhalb weniger Sekunden nach Beendigung des jeweiligen Rauchzuges unter dynamischen Bedingungen die Ventilation und gleichzeitig die Konzentration einer Rauchkomponente bestimmt. 
Mit unterschiedlichen Ventilationsmodellen $(0,13,30$, $40,60,75$ und $90 \%$ ) wurden Versuche gemacht, wobei die Ventilation jeder Zigarette vor dem Abrauchen mittels der CORESTA-Standardmethode unter statischen Bedingungen gemessen wurde. Die so erhaltenen Werte stimmten gut mit jenen überein, die unter Einsatz des neuen Verfahrens ermittelt wurden.

Die Befunde bestãtigten, daß die Konzentration der untersuchten Verbindung im Hauptstromrauch mit dem Rückgang der Fillterventilation von $90 \%$ auf Null zunimmt. Bezogen auf die Zugzahl stieg die Ventilation während der ersten Züge leicht an und nahm in den folgenden Zügen $a b$, während die Ausbeute an dem untersuchten Rauchinhaltsstoff mit steigender Zugzahl zunahm. Im Vergleich zu den Ventilationsverhältnissen in der Zigarette in nicht brennendem Zustand verànderte sich die Ventilation während des Abrauchvorganges bei $40 \%$ iger Filterventilation am stărksten.

\section{RESUME}

Les auteurs de ces experiences ont mis au point un système assisté par ordinateur de spectrographie infrarouge a haute résolution par laser à diode accordable (TDL) en vue de la détermination simultanée, d'une part, de la concentration d'un composant de la phase gazeuse (monoxyde de carbone) et, d'autre part, du taux de ventilation du filtre pendant le fumage d'une cigarette. L'acquisition simultanée de ces deux paramètres pourrait influer favorablement sur la mise au point d'un nouveau type de cigarettes.

Expérimentalement, l'approche choisie consiste à placer la cigarette de façon à ce que les trous de ventilation au niveau du filtre se trouvent dans une enceinte remplie d'un gaz n'existant normalement pas dans la fumé l'oxyde nitreux $\mathrm{NO}_{2}$, par exemple - lequel est mélangé à la fumée de cigarette dans les conditions habituelles du fumage. Tandis que l'oxyde nitreux fournit des informations sur le taux de ventilation, le constituant représentatif de la fumée renseigne sur le flux principal de la fumée. A la connaissance des auteurs, c'est la première fois que l'on est parvenu à déterminer à la fois le taux dynamique de ventilation et la concentration d'un composant de la fumée et ce, quelques secondes après chaque bouffée.

Des expériences ont été effectuées avec des cigarettes à différents taux de ventilation $(0,13,30,40,60,75$ et $90 \%$ ), le taux de ventilation statique étant déterminé avant le fumage pour chaque cigarette a l'aide de la méthode standard coresta. Les résultats ainsi obtenus présentent une bonne concordance avec les valeurs trouvées en utilisant le nouveau procédé (TDL).

Les résultats confirment que la concentration du constituant examiné dans le flux principal augmente lorsque le taux de ventilation du filtre décroît de $90 \%$ à 0 . Par rapport au nombre de bouffées, le taux de ventilation s'accroît légèrement pendant les premières bouffées pour décrôttre par la suite tandis qu'on recueille une quantité croissante du constituant gazeux étudié lorsque le nombre de bouffées augmente. Comparativement à la valeur statique (déterminée lorsque la cigarette n'est pas allumé), c'est pour les cigarettes ayant un taux de ventilation de $\mathbf{4 0} \%$ que la variation de ventilation pendant le fumage est la plus importante.

\section{INTRODUCTION}

During the past decade there has been rapid growth in the use of ventilated filter cigarettes, which has led to extensive research to describe the relationship between filter ventilation and cigarette smoke delivery (1-13). Several studies have been reported $(2,3,5,10,12)$ which measured dilution and/or filter ventilation of a cigarette while smoking. Some of these studies also presented data on the delivery of selected cigarette smoke components. However, for the most part, in filter ventilation studies, quantitative values of smoke components have not been determined for individual puffs but have been reported for the entire cigarette and then a per puff calculation was performed.

In most cases one experiment was required to obtain the filter ventilation level for each puff on a lit cigarette and a second experiment was required to obtain quantitative information of the smoke components. It would be desirable to obtain both parameters simultaneously for each puff so that the relationship of filter design and ventilation to the dilution in cigarette smoke delivery could be more fully characterized. Any analytical technique capable of accomplishing this task must have three essential characteristics. The technique must provide quantitative data on the smoke component of interest within seconds of taking a puff. The speed of such a technique also will reduce the chance for reactions and artifact formations to take place, which occur due to aging of cigarette smoke (14). Because of the requirement of fast analysis time, the technique must be specific and free from interferences from other components in cigarette smoke. There is no time for elaborate separation schemes and, therefore, the second essential requirement the technique must provide is ultra-high resolution. The third requirement of the technique is to have adequate sensitivity for accurate detection of the smoke component of interest. An analytical technique which meets the above requirements has been developed recently and is called tunable diode laser (TDL) infrared spectroscopy. An excellent detailed description of this technique is given by Scklossberg and KrLLEY (15) and therefore only a brief discussion of the principles of the TDL is provided here.

The diode laser spectrometer when compared to conventional infrared spectrometers provides increased sensitivity, high speed, specificity and resolution, with the limitation that only a small number of gaseous species can be monitored simultaneously. However, because of the above-mentioned attributes of the diode laser instrument, cigarette smoke investigations can be 
accomplished in real time without prior separation, making the technique particularly well suited for puffby-puff analyses.

Commercially available tunable diode lasers generally operate in the range of $500 \mathrm{~cm}^{-1}$ to $3500 \mathrm{~cm}^{-1}$. The diode lasers are fabricated from lead salt semiconductor crystals with various compositions. The laser cavity is made by cleaving opposite ends of the crystal. The crystal diode is rigidly mounted on a support block and electrical contacts are made. The application of $0.5 \mathrm{~A}-2.0 \mathrm{~A}$ current causes lasing action by producing a population inversion between the almost filled valence band in the active region of the laser crystal. The frequency of the laser radiation is determined by the composition of the crystal. Diodes operate at temperatures between $15 \mathrm{~K}$ and $75 \mathrm{~K}$. The diode wavelength is tuned by varying the operating temperature of the diode. A diode covers a frequency range from $10 \mathrm{~cm}^{-1}$ to $150 \mathrm{~cm}^{-1}$. In practice the output of the diode laser contains multiple frequencies corresponding to the longitudinal modes supported by the Fabry-Perot cavity formed by the cleaved faces. These modes are separated by $\Delta v=\mathrm{c} / 2 \mathrm{nl}$, where $\Delta \mathrm{v}$ is the mode separation, $\mathrm{c}$ is the speed of light, $l$ is the cavity length and $\mathrm{n}$ is the refractive index of the laser material. Since a single frequency is needed, a monochromator is required to adequately separate the modes.

The line width of a TDL is extremely narrow and allows Doppler limited absorption spectra to be obtained. This characteristic, combined with the fast response of the TDL, permits the laser frequency to be rapidly modulated and therefore allows the spectral range of interest to be scanned rapidly. These fundamental characteristics of the TDL make it possible to measure accurately small absorbances due to a single rotational-vibrational line of the infrared spectrum of a molecule. The TDL is capable of detecting molecules at the part per billion volume ( $\mathrm{ppbv}$ ) levels when used in conjunction with a long path length cell. If the cell pressures are reduced to below 35 Torr, interferences with other gases are minimized. This is the attractive feature of the TDL because the accurate measurement of a particular species can be made even in the presence of a complex matrix such as cigarette smoke.

The objective of this work was to measure simultaneously, using TDL spectroscopy, the concentration of a cigarette smoke component and the filter ventilation level within seconds after each puff was taken. The approach selected to accomplish this objective was to place the filter end of a cigarette in a glass chamber filled with a gas not normally detected in cigarette smoke. This approach was similar to that reported by Newsome and KeIrt (1) in which nitrogen was used and by ReYNolds and W HeELER (5) in which argon was used. In this work nitrous oxide $\left(\mathrm{N}_{2} \mathrm{O}\right)$ was the gas selected because it does absorb in the infrared region. When a $35 \mathrm{ml}$ puff was taken, the $\mathrm{N}_{2} \mathrm{O}$ in the chamber was drawn through the filter ventilation holes and combined with the cigarette smoke under actual smoking conditions. By selecting a TDL with the appropriate tuning range, the molecular absorption lines for both $\mathrm{N}_{2} \mathrm{O}$ and a representative smoke component could be measured simultaneously for each puff. For this work the representative smoke component was carbon monoxide. The degree of filter ventilation was calculated from the amount of $\mathrm{N}_{2} \mathrm{O}$ drawn through the ventilation holes of the cigarette filter. A brief description of this research technique has been offered previously in a review (16). In this current paper the TDL technique and procedure for generating the data are discussed in greater detail and results obtained for model cigarettes having seven different filter ventilation levels are examined.

\section{EXPERIMENTAL}

\section{Optical Layout}

A diagram of the optical system based on the TDL LS-3 spectrometer* is shown in Figure 1. The infrared radiation from the diode laser ${ }^{* *}$ which was mounted in a cryogenic closed-cycle refrigerator ${ }^{* *}$ was collected and collimated by an f/1 KRS-5 lens. This collimated radiation passed through a compartment that houses a reference gas cell and a $75 \mathrm{~mm}$ solid $\mathrm{Ge}$ etalon. The reference gas cell contained the cigarette component to be monitored which for this work was carbon monoxide. This reference cell was used to identify the absolute frequency of the TDL radiation from the known positions of the molecular absorption lines of the reference gas. The solid Ge etalon was used to find the frequency of the TDL between the known reference absorption lines. This was necessary since the tuning of the TDL can be highly non-linear. The TDL radiation, after passing through the sample compartment, was focused onto the entrance of a $4.17 \mathrm{~m}$ base pathlength White cell $^{+}(17)$. The radiation after passing through the cell was focused on the exit aperture of the cell. Transfer optics recollimated the radiation and then focused the radiation onto the entrance slits of the LS-3 monochromator section. The radiation was mechanically chopped at the entrance slits by a tuning fork chopper $^{++}$. This was done because an A.C. detection system was used. The monochromator was used to isolate a single TDL mode from the multi-mode (multiple frequency) TDL radiation. The separated mode passed through the exit slits of the monochromator where transfer optics focused the radiation onto a liquid nitrogen cooled indium antimonide (InSb) detector ${ }^{+++}$.

\footnotetext{
* Spectra Physics, Laser Analytics Division, Bedford, Mass-, 01730, U.S.A.

"* Model SP5610, Spectra Physics.

*t* Model 21, Cryogenic Technology Inc. (CTT), Waltham, Mass., 02154, US.A.

+ Model LO-3-2, Spectra Physics.

++ Model L2, American Time Products, Woodside, N.Y., 11377, U.S.A.

+H Model 40742, Santa Barbara Research Center, Goleta, Calif., 93017, US.A.
} 


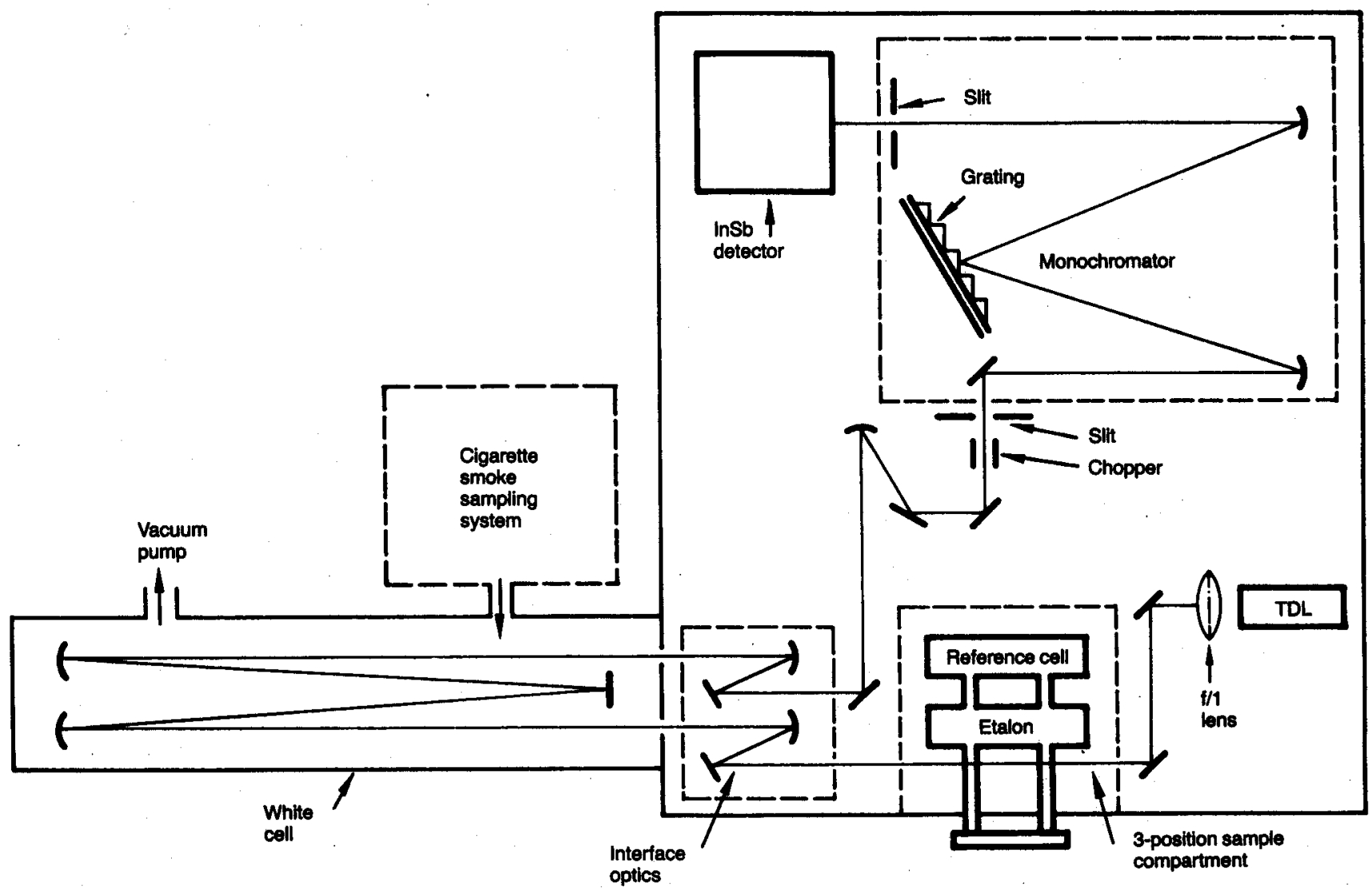

The signal from the InSb detector was proportional to the amount of radiation passing through the White cell and was demodulated by a lock-in amplifier ${ }^{x}$ referenced to the tuning fork chopper frequency. The output of the lock-in, which had a one-volt maximum value, was offset by one-half volt. Then the output was D.C. amplified by a preamplifier ${ }^{\mathrm{x}}$ to bring it up to the \pm fivevolt level required by the analog to digital converter (ADC) on either the MINC 11/03 or DECLAB 11/23 microcomputer ${ }^{\mathrm{rx}}$ used to take the data and control the experiment. The offset and amplification were needed to take advantage of the full dynamic range of the 12-bit ADC.

\section{Computerized Gas Transfer System}

Figure 2 shows the gas transfer system used to sample the whole cigarette smoke. The ventilation chamber in which the cigarette filter was inserted was made of glass and had rubber dental dams which sealed the $\mathrm{N}_{2} \mathrm{O}$

\footnotetext{
$x$ Model 128A, Princeton Applied Research (PAR), Princeton, N.J., 08540, U.S.A.

xx Model 113, PAR, Princeton, NJ.

xox Digital Equipment Corp., Maynard, Mass., 01754, U.S.A.
}

supplied from a pure $(>99 \%) \mathrm{N}_{2} \mathrm{O}$ cylinder*. The filter end of the cigarette was inserted through a dental dam so that the ventilation holes were exposed to the $\mathrm{N}_{2} \mathrm{O}$ in the chamber. The very tip end of the filter was inserted into a second dental dam fastened to a glass tube which was supported by a \#4 rubber stopper placed in the other end of the ventilation chamber. The glass tube passed through the stopper and was connected to the input solenoid (A) of a one-port, syringe type smoking machine. The solenoids ${ }^{* *}$ labeled $A, B$, $\mathrm{C}, \mathrm{D}$ and $\mathrm{H}$ in Figure 2 were electromechanical in nature and were operated by a computer-controlled interface.

The ventilation chamber combined with a pressure control system was the most critical part of the sampling system. The pressure control system ${ }^{* \star *}$ in Figure 2 consisted of a pressure/flow controller (Model \#250A) used in this application as a pressure controller, a 1 Torr Baratron differential pressure gauge (Model \#310 CD-00001), a flow control valve (Model \#248-K-

\footnotetext{
" Matheson Gas Products, East Rutherford, N.J., 07073, U.S.A.

** Skinner Model V53DA1075, Virginia Carolina Controls, Richmond, V2., 23226, U.S.A.

*** MKS Instruments, Inc., Burlington, Mass., 01803, U.S.A.
} 
Figure 2.

Clgarette smoke sampling system.

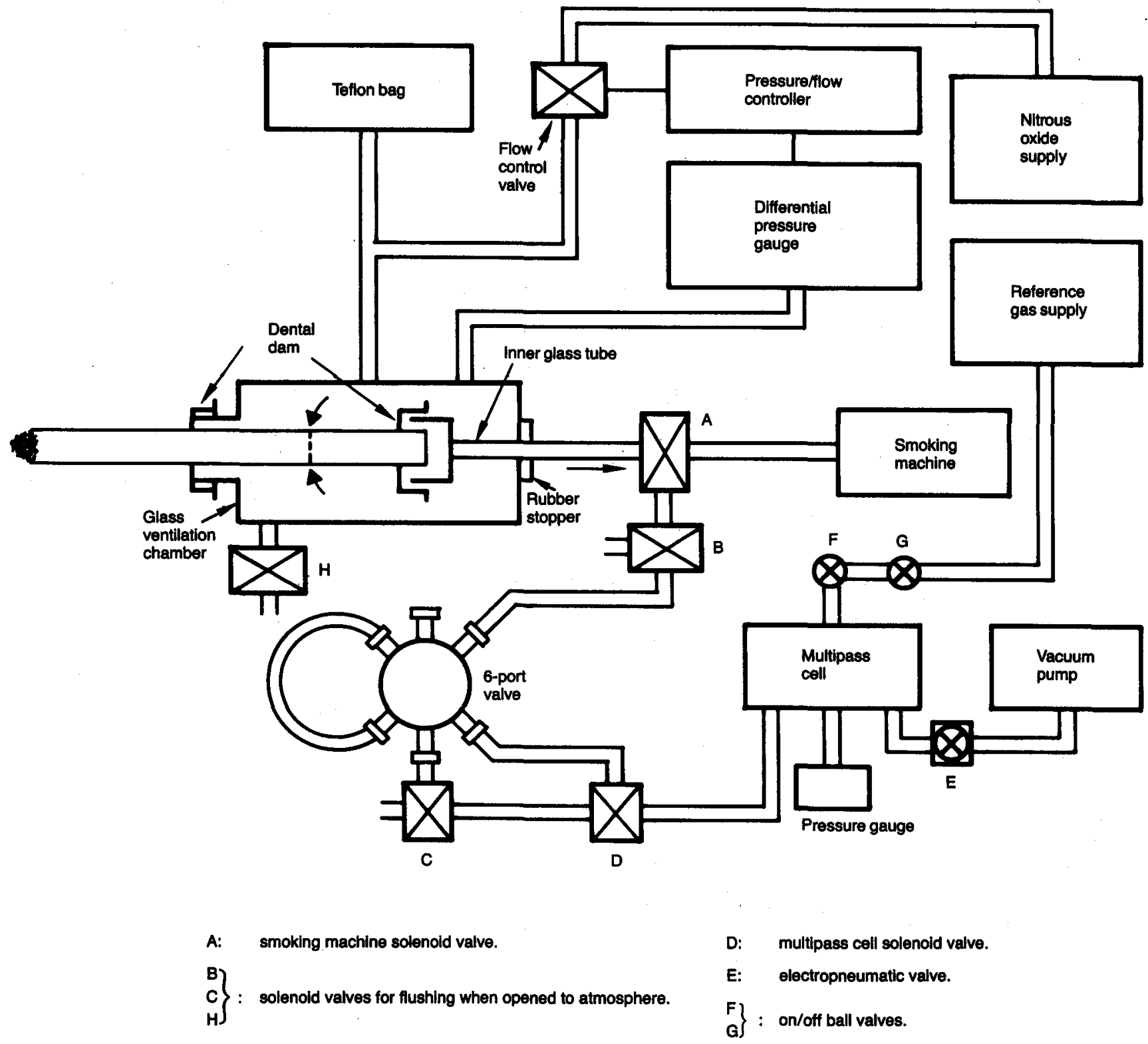

2000S) and a 7.71 Teflon bagt. This design not only minimized atmospheric contamination but also substantially reduced contamination from cigarette smoke which sometimes backstreamed into the chamber through the cigarette ventilation holes when the cigarette puff was completed. This minimization of contamination was accomplished by having the pressure controller, which was connected to the ventilation chamber, maintain a very slight positive pressure of $<100$ milliTorr in the $\mathrm{N}_{2} \mathrm{O}$ chamber at all times, especially during the cigarette puff. Between puffs, $\mathrm{N}_{2} \mathrm{O}$ was swept through the chamber by allowing it to escape through 2 controlled leak using solenoid $H$. This

\footnotetext{
+ Allech Associates, Inc., Deerfield, Ill, 60015, U.S.A
}

sweeping of the chamber removed the backstreamed smoke from the chamber. Tests carried out on this system indicated that the use of the pressure controller and controlled $\mathrm{N}_{2} \mathrm{O}$ leak substantially improved the reproducibility and accuracy of the ventilation measurements because the smoke contamination in the ventilation chamber was decreased to minimal values. A photograph of the ventilation chamber is shown in Figure 3.

After a cigarette puff was taken, the smoke was pushed through solenoid A, through a $1 \mathrm{ml}$ nickel sample loop connected to a 6-port gas sample valve ${ }^{++}$and then ex-

\footnotetext{
++ Model AH-LV-6-HPA-HC, Valco Industries, Houston, Tex, 77055, U.S.A.
} 
Figure 3.

Photograph of ventilation chamber.

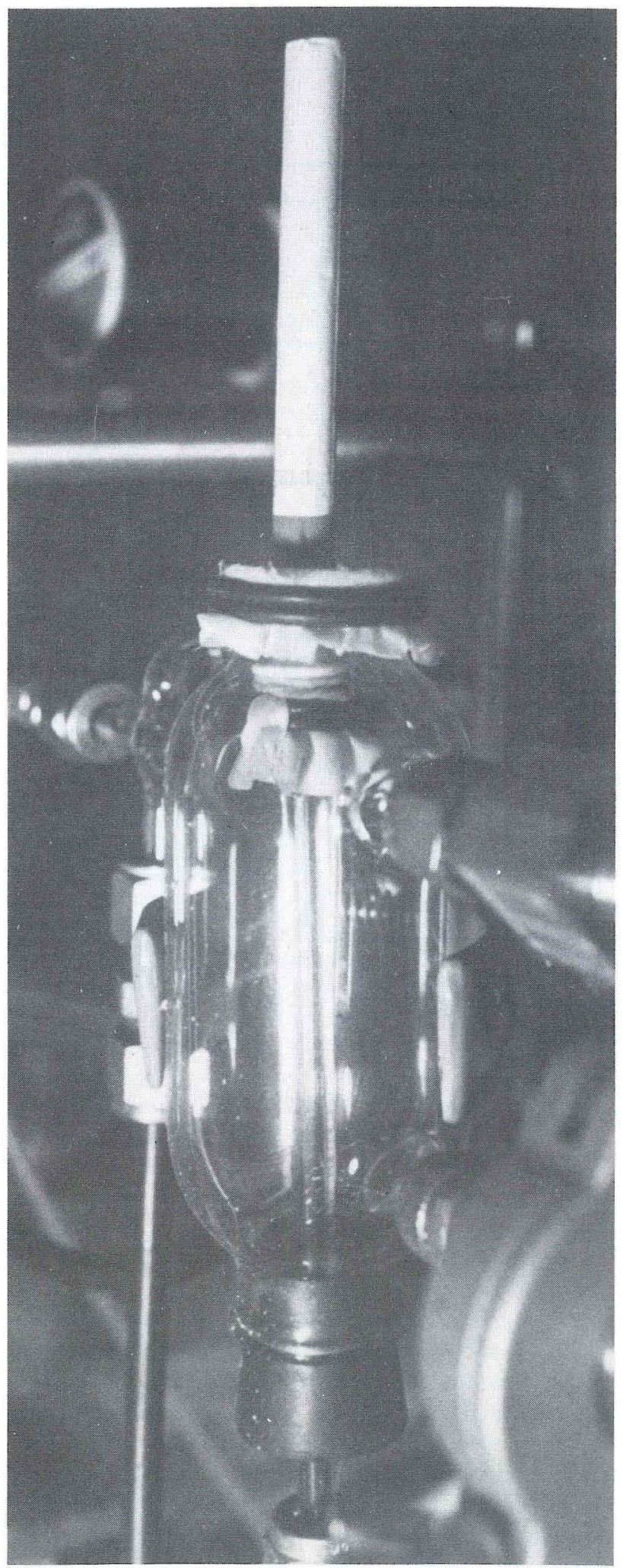

hausted to the atmosphere through solenoid C. The $1 \mathrm{ml}$ smoke sample was emptied into the $13.2 \mathrm{l}$ volume White cell via the gas sample valve and solenoid $\mathrm{D}$. The insertion of only $1 \mathrm{ml}$ of smoke from the $35 \mathrm{ml}$ puff was necessary because of the strength of the molecular absorption lines of the smoke component and $\mathrm{N}_{2} \mathrm{O}$ which were used. If the full $35 \mathrm{ml}$ puff volume were used, then the line centers of the molecular absorption lines would have been saturated and accurate measurements would not have been possible. Also, pressure broadening effects were decreased by using only $1 \mathrm{ml}$ of the smoke sample. Therefore the molecular absorption lines were much narrower, which permitted easier detection of small sample concentrations. After the spectra of the smoke sample were taken with the TDL, the White cell was evacuated in less than 30 seconds by opening the electropneumatic valve ${ }^{+++}(\mathrm{E})$ to a 50 c.f.m. vacuum pump ${ }^{x}$. In addition to evacuating the cell, the sample gas lines connecting solenoid A to the White cell were flushed for a few seconds to clean out any residual smoke. This was accomplished by opening solenoid D to the 6-port valve, closing solenoid $\mathrm{C}$ to the atmosphere, and opening solenoid $\mathrm{B}$ to the atmosphere. Flushing between puffs reduced the dead volume carry-over from one puff to the next by $\sim 70 \%$.

The manual valves ${ }^{\mathrm{xx}} \mathrm{F}$ and $\mathrm{G}$ in Figure 2 were used to insert a pure sample of the reference gas into the White cell to check the true optical zero. This was different from the optical zero obtained by blocking off the TDL radiation because small extraneous TDL modes were not optically filtered by the monochromator.

\section{Electronic Configuration}

The electronics necessary to conduct this study are shown in Figure 4. The basic part of the control of the experiment was provided by a small microcomputer. During the early phase of the work a MINC 11/03 microcomputer with floppy disks was used. The DECLAB $11 / 23$ which had two 10.8 megabyte hard disks was used in the later part. The configuration of both was the same. The main parts of the microcomputer fit into the $\mathrm{Q}$ bus (backplane) as modules. These modules were as follows: two programmable clocks, one 16-bit digital output unit, one 12-bit analog to digital converter (ADC), one 12-bit digital to analog converter (DAC) and a graphics console terminal. The modulated signal at the InSb detector was displayed on channel B of the oscilloscope $^{\mathrm{xxx}}$ and was demodulated synchronously by the lock-in amplifier which was referenced to the $400 \mathrm{~Hz}$ reference of the chopper. This output was offset and then amplified by the D.C. preamplifier and then the D.C. signal was digitized by the ADC microcomputer. The spectra of the gases in the White cell were obtained by digitizing this D.C. signal as the current through the TDL was increasing. The ramping of this current was provided by a ramp generator*. This ramp generator output was applied to the modulation input on the TDL current supply as well as to the input

\footnotetext{
* Model 143, Wavetek, San Diego, Calif., 92123, U.S.A.

x Model 2T20603, Alcatel Vacuum Products, Kingham, Mass., 02043, U.S.A.

xx SS-42S4, Whitey Co., Highland Heights, Ohio, 44143, U.S.A.

xxx Model T922R, Tektronics, Inc., Beaverton, Oreg., 97077, U.S.A.

${ }^{+++}$Model 26-411 KFEU, HPS Corp., Boulder, Colo., 80301, U.S.A.
} 
Figure 4.

Electronic schematic.

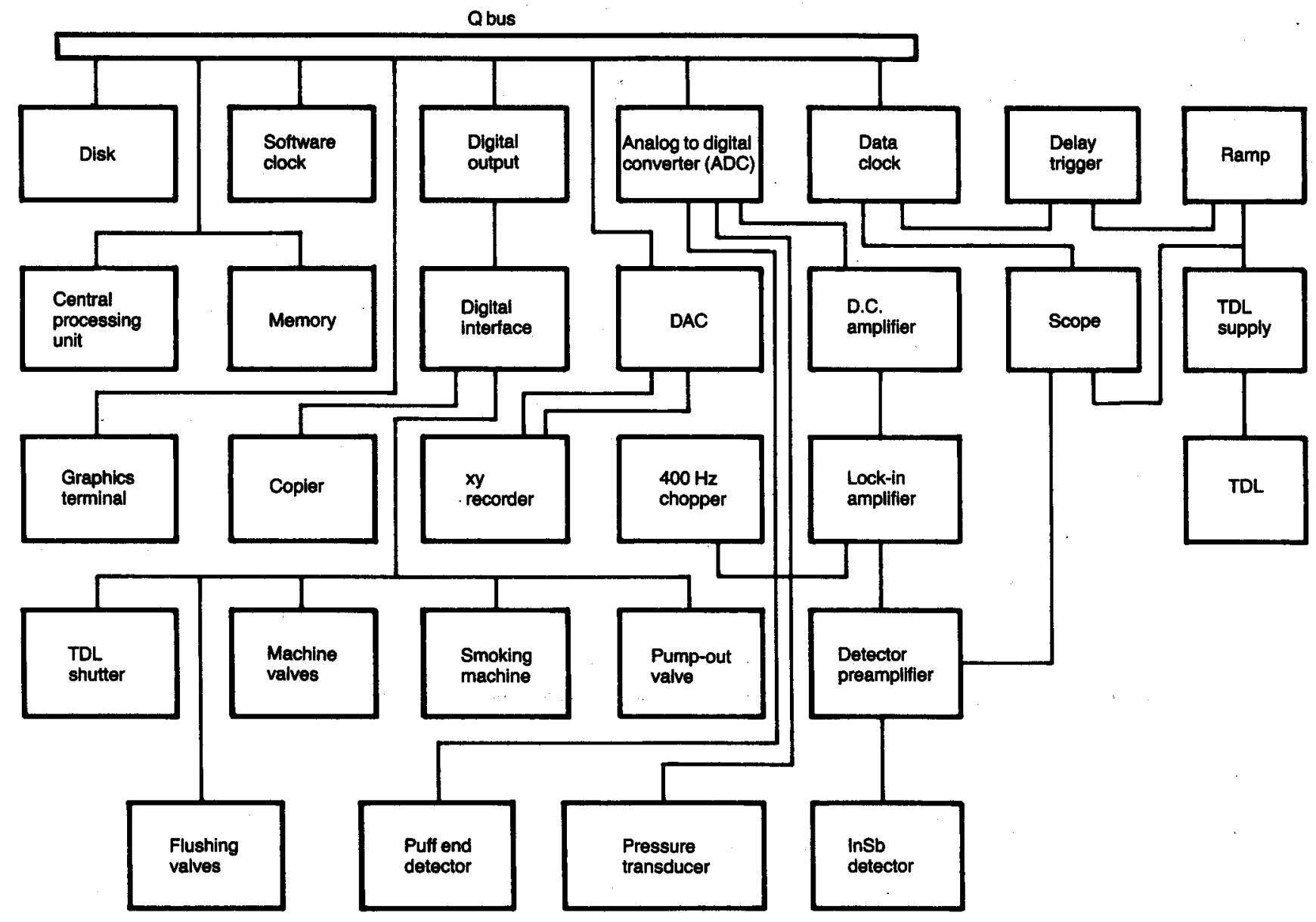

to channel $A$ of the oscilloscope which was used for monitoring purposes. The approximate one-volt ramp output drives the TDL frequency through $0.1 \mathrm{~cm}^{-1}$ which was more than sufficient to scan the TDL through both the smoke component and $\mathrm{N}_{2} \mathrm{O}$ molecular absorption lines. The ramp generator also provided a synchronization signal to the delay generator ${ }^{\text {** }}$ which delayed the start of the data acquisition $1 / 3$ second to allow the TDL frequency to stabilize at the end of the ramp cycle. The use of the ramp generator with its repetitive waveform improved the reproducibility of the spectra taken with the TDL because it reduced wavelength hysteresis effects. The primary clock or data clock initiated the data acquisition cycle after receipt of a signal from the delay generator. The second programmable clock or software clock was used to time the length of a puff during the smoking cycle. In order to display the raw data taken, the DAC was used to

\footnotetext{
+ Model 4932, Tektronics, Inc., Beaverton, Oreg., 97077, U.S.A.

+ Model 220BHS-2A4-B-1, MKS Instruments, Inc., Burlington, Mass., 01803, U.S.A.

** Model 182A, Wavetek, San Diego, Calif., 92123, U.S.A.

*** Model 7047A, Hewlett-Packard, San Diego, Calif., 92127, U.S.A.
}

drive the $x$ and $y$ inputs of the $x y$ recorder***. The digital output module on the microcomputer was used to control all of the solenoid valves, the TDL shutter for baseline zero determination, the smoking machine and the graphics screen video hard copy unit ${ }^{+}$. This control was exerted via the digital interface and was implemented by sending different digital values to the digital output module which actuated the required digital line. The ADC also was used to digitize the output of a 0-1 Torr Baratron pressure gauge ${ }^{++}$which measured the pressure in the White cell. In addition, the ADC was used to determine when the coal of the cigarette had reached the position of $3 \mathrm{~mm}$ from the tipping paper. This was done by sensing the voltage across a microswitch that was closed by tightly drawing a string across the switch lever at the tipping paper plus $3 \mathrm{~mm}$ position. When the cigarette burned the string, the microswitch was opened and a voltage occurred across the switch and stopped the smoking process.

\section{Calibration and Standardization}

The absolute calibration of the system response was determined by withdrawing $35 \mathrm{ml}$ samples from a 2.61 
Figure 5.

Data acquialtion cycie.

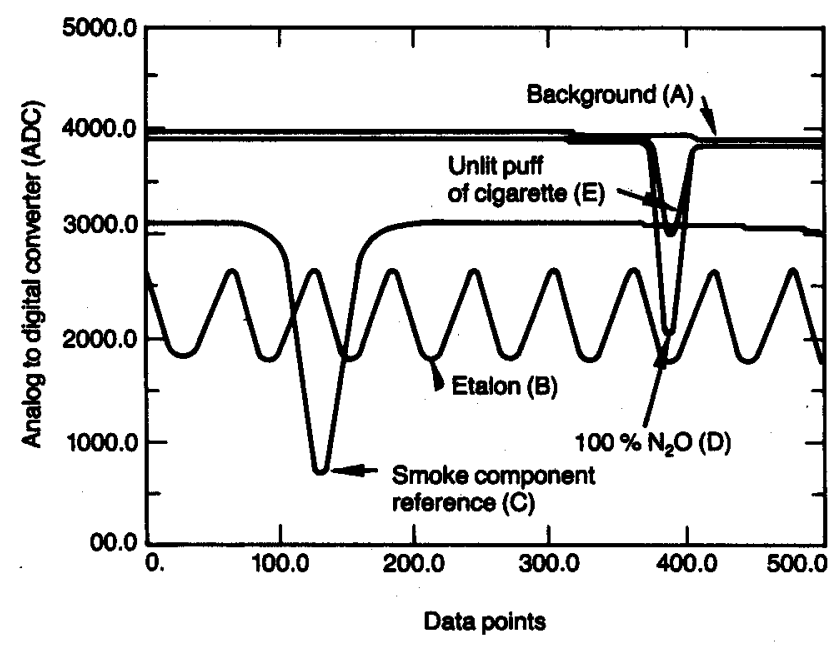

Teflon sampling bag ${ }^{+++}$containing standard samples of the carbon monoxide in $\mathbf{N}_{2}$. The samples with concentrations covering the working range were drawn from the bag and injected into the White cell in the same manner as used for cigarette smoke sampling. The ventilation for a given puff was determined by taking the ratio of the $\mathrm{N}_{2} \mathrm{O}$ line center absorbance which was calculated from the molecular line center transmittance, to the line center absorbance for a pure $\mathrm{N}_{2} \mathrm{O}$ sample. The line center absorbance for a pure $\mathrm{N}_{2} \mathrm{O}$ sample was obtained by inserting a solid plug in the outer dental dam in the ventilation chamber and then drawing a sample of pure $\mathrm{N}_{2} \mathrm{O}$ into the system in exactly the same way as smoke was drawn. The filter ventilation is given by the equation

$$
\mathrm{D}_{\mathrm{i}}=-\ln \left(\mathrm{T}_{\mathrm{i}-\mathrm{N}_{2} \mathrm{O}}\right) /\left(-\ln \left(\mathrm{T}_{\text {pure }}\right)\right),
$$

where $D_{i}$ is the ventilation for the $i$-th puff, $T_{i-N_{2} O}$ is the transmittance at the $\mathrm{N}_{2} \mathrm{O}$ line center for the i-th puff, $T_{\text {pure }}$ is the transmittance at line center for the pure $\mathrm{N}_{2} \mathrm{O}$ sample. Standard ventilation calibration tubes $^{x}$ were used to check the accuracy of the ventilation determinations. These ventilation tubes were inserted into the ventilation chamber in place of the cigarette and then "smoked" as a cigarette. The ventilation was calculated from the $\mathrm{N}_{2} \mathrm{O}$ line center transmittance and then compared to the ventilation determined by the CORESTA standard ventilation method (18). The experimental (TDL) ventilation values agreed with those of the CORESTA method within $\pm 1 \%$ ventilation unit (VU).

\section{Cigarette Model System}

The physical characteristics of the cigarettes used in this study were: total length of $80 \mathrm{~mm}$ with a cellulose acetate filter of $19 \mathrm{~mm}$, tipping paper length of $23 \mathrm{~mm}$, cigarette paper porosity of 23 Greiner number $(25$ cORESTA units), and circumference of $25 \mathrm{~mm}$. The cigarettes were conditioned at $74{ }^{\circ} \mathrm{F}\left(23^{\circ} \mathrm{C}\right)$ and $60 \%$ relative humidity and then weight selected ( $950 \pm 5 \mathrm{mg}$ ), screened for resistance to draw $(4.10 \pm 0.1$ inches of water) using the pressure drop procedure and ventilation $(13 \pm 1 \%)$. The ventilation on the cigarettes was modified manually so that they had ventilation values targeted at $30 \%, 40 \%, 60 \%, 75 \%$ and $90 \%$ ( $\pm 1 \%$ VU) using the CORESTA standard ventilation method at a flow rate of $17.5 \mathrm{ml} / \mathrm{s}$. For example, the expression 90 $\pm 1 \%$ VU should be interpreted to mean a range of ventilation from $89 \%$ to $91 \%$. The experimental TDL ventilation values agreed with the values determined by the CORESTA procedure within the accuracy of this $\operatorname{method}( \pm 1 \% \mathrm{VU})$.

\section{Procedure}

The entire experiment was under the control of the microcomputer. The microcomputer had been programmed to take some preliminary spectra before the actual smoking of the cigarette began. The procedure was begun by blocking off the TDL radiation with an electromechanical shutter, followed by recording five spectra to determine the system's baseline zero. This baseline value was determined by averaging all the points taken in each of the five spectra. The reference cell with the smoke component sample was inserted into the TDL path and five spectra were taken. Each of the five spectra was recorded sequentially by the microcomputer on the system's storage disk. These spectra, which consisted of 512 points each, were then co-added and plotted on the xy recorder after the system's baseline zero was subtracted. The smoke component reference spectrum is labeled $C$ in Figure 5. All spectra taken received this same treatment. After this, the reference cell was removed from the path and the solid $\mathrm{Ge}$ etalon was inserted. Five etalon spectra were taken and displayed (labeled $B$ in Figure 5). The distance between two peaks in the etalon spectra represents $0.0162 \mathrm{~cm}^{-1} \pm 1 \%$. The etalon was removed and background spectra were taken with the White cell evacuated (labeled A in Figure 5). This was necessary to determine the transmittance for the other spectra taken. The ventilation chamber was flushed with pure $\mathrm{N}_{2} \mathrm{O}$ to remove any atmospheric contamination and a solid plug was inserted into the first dental dam. The same exact gas sampling procedure as used in the smoking process was used to draw in a pure $\mathrm{N}_{2} \mathrm{O}$ sample into the White cell. The spectra taken in this case gave the $100 \%$ ventilation result (labeled D in Figure 5). The microcomputer also measured and recorded the pressure in the White cell by digitizing the output of the $0-1$ Torr pressure gauge. Since the cell pressure could vary by $\pm 5 \%$ from injection to injection, it was necessary to record the cell pressure because the ab-

\footnotetext{
$x^{x}$ Lurex, Vineland, N.J., 08360, U.S.A.

++t Alltech Associates, Inc., Deerfield, Ill, 60015, U.S.A.
} 
sorbance at the centers of the molecular lines were directly proportional to the pressure. The solid plug was removed from the dental dam, a cigarette was inserted in its place and the White cell was evacuated. Then an unlit puff was taken on the cigarette and spectra were taken to determine the cigarette ventilation prior to smoking (labeled $E$ in Figure 5). After the White cell was evacuated, the actual cigarette smoking commenced with the lighting of the cigarette. The smoking machine was controlled by the microcomputer, which scheduled cigarette puffs at 1 minute intervals. The smoking machine was set to take a $35 \mathrm{ml}$ puff of $2 \mathrm{~s}$ duration. The microcomputer controlled the injection of the smoke sample into the White cell, recorded spectra and pressure for each puff, displayed the spectra, evacuated the cell, and timed the system for the next puff to start. An example of the spectra for the unlit puff and seven smoking puffs of a typical cigarette is given in Figure 6. The absorption line on the left was due to the smoke component and the one on the right was due to $\mathrm{N}_{2} \mathrm{O}$. The experiment ended when the string, which was placed $3 \mathrm{~mm}$ ahead of the tipping paper, burned through, releasing the microswitch lever. If the string broke during a puff, the software clock measured the length of the partial puff. Once the string broke or 15 puffs were taken, the computer program requested information about the experiment. Once this information was entered, the spectral file on the disk was closed.

After the data acquisition program had finished, a second program was loaded into the microcomputer to perform the data analysis. This program began by loading into memory the information about the experiment that was typed in the computer during the data gathering phase. This was printed out on a line printer along with the number of puffs, and the fractional puff, if a partial puff occurred. Then the magnitude of the signal, due to extraneous modes which were transmitted through the monochromator, was entered into the computer to correct the experimental data for this problem. This information was obtained in a separate experiment in which 0.2 Torr of reference gas was injected into the White cell. This amount of reference gas was sufficient to cause the line center absorption to be complete. Therefore, the signal at the line center of the reference gas absorption line was due to the extraneous modes, and this was the value that was entered into the computer. After this, the etalon spectra were read into the computer memory and co-added. The tentative etalon peaks were located by using the averaged numerical derivative to find the positions where the derivatives changed signs from positive to negative. The coadded spectrum was displayed on the graphics terminal and these tentative etalon peaks were marked on the screen. Improperly chosen peaks could be identified and removed from consideration by inserting these peak numbers into the computer. Each of the remaining peaks had a least squares quadratic equation fitted to the etalon spectra around these pealks. The fitted curves allowed more accurate determination of the peak cen-
Figure 6.

Cigarette component and $\mathrm{N}_{2} \mathrm{O}$ spectra for unlit puff and seven smoking puffs.

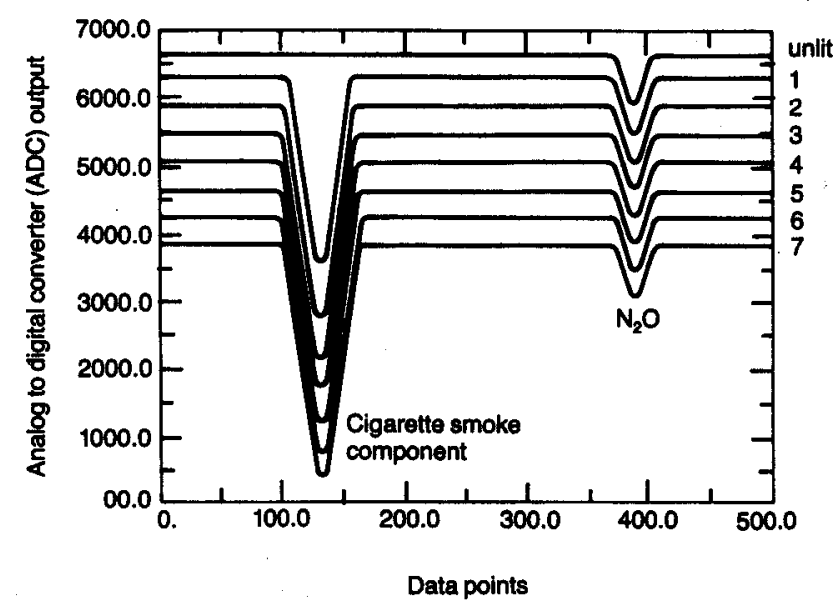

ter. These peak centers were used to linearize all subsequent TDL wavelength scales. The analysis program read the first reference spectrum into the computer. The position of the reference line center was determined from this spectrum by determining where the average numerical derivative of the spectrum changed sign from negative to positive. This line center position was stored in the computer for later use. The data associated with the first spectrum for the $100 \% \mathrm{~N}_{2} \mathrm{O}$ trial were entered into the computer memory and processed to determine the position of the $\mathrm{N}_{2} \mathrm{O}$ line center in the same manner as the above reference spectrum. This value also was stored in the computer for later processing.

Once the two line center positions were recorded, then the computer read into memory each of the individual spectra taken during the data acquisition. Since the position of the line centers of the individual lines had been found to vary from one individual spectrum to the next, it was necessary to process each spectrum to determine the position of the reference and $\mathrm{N}_{2} \mathrm{O}$ lines. The processing was minimized by using data only within \pm 50 data points around the position of the line centers previously found for the reference and $\mathrm{N}_{2} \mathrm{O}$ lines respectively.

\section{RESULTS AND DISCUSSION}

Data obtained from puff-by-puff cigarette whole smoke analysis normally demonstrated a relatively high level of variation primarily due to the dynamic physical and chemical processes occurring during the combustion of the tobacco. In order to be successful in relating changes in a physical parameter of a cigarette, such as filter ventilation, to the smoke delivery of a cigarette, two essential requirements were necessary. First, the cigarettes within each type used in the study must be as 
Figure 7.

Illustration of precision of ventllation measurements.

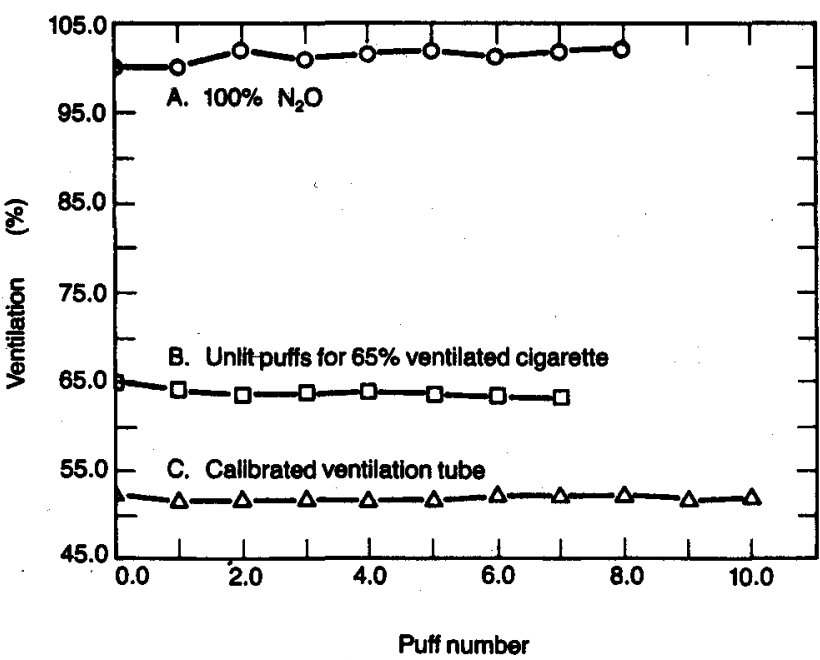

similar as possible, and second, the error of the instrumental analysis system should be reduced to as minimal a level as feasibly possible. This study required the error for measuring the ventilation to be reduced to $1 \%$ VU since the observed changes from puff to puff were in this same range.

To achieve this level of precision, several conditions were required. First, all manual operations of the experimental and data collection procedures had to be performed using a computer. This necessitated the design and construction of a computer interface and the development of extensive software for the MINC microcomputer system. Second, a ventilation chamber with adequate pressure control devices was required to minimize atmospheric contamination and smoke back-diffusion while the cigarette puff was taken. Third, a low dead volume gas sampling valve was selected to insure that a reproducible and precise amount of smoke entered the infrared gas cell for analysis. Low dead volume solenoid valves were used for an automated se-

Figure 9.

Ventilation and smoke component dellverles for $\mathbf{4 0} \%$ ventilated cigarettes (average of 4 determinations).

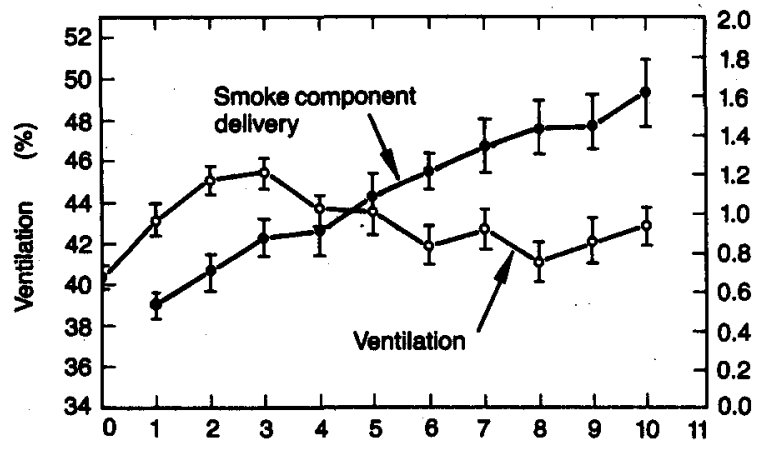

Pulf number
Figure 8.

Ventliation and smoke component deliverles for $90 \%$ ventflated cigarettes (average of 4 determinations).

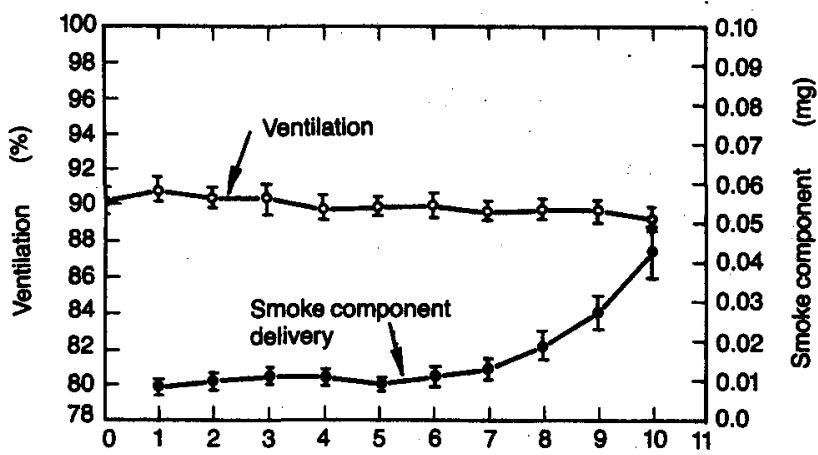

Puff number

quence of flushing of all sampling lines, valves and the gas cell between puffs. The combination of the above items resulted in an accurate procedure for monitoring the change in the ventilation level as the cigarette was smoked. Figure 7 illustrates the precision of the technique. The top curve (A) was obtained by taking repeated puffs of $100 \% \mathrm{~N}_{2} \mathrm{O}$ using the Teflon plug to seal the ventilation chamber from the atmosphere. The standard deviation for 8 puffs was $\pm 0.6 \%$ VU. The middle curve (B) was obtained by taking unlit puffs using a cigarette measured by the corista ventilation method to have a ventilation of $65 \%$. The standard deviation for 7 puffs from the unlit cigarette was $\pm 0.6 \%$ VU. The bottom curve (C) was obtained by taking puffs using a calibrated ventilation tube $(52 \%$ by the static method). The standard deviation for 10 puffs was $\pm 0.6 \% \mathrm{VU}$. All three experiments produced results of excellent precision indicating that this procedure is capable of distinguishing differences in cigarette ventilation of less than $1 \%$ VU. The accuracy of the ventilation measurements by the TDL procedure was determined by comparing the results using the calibrated ventilation tubes with results of the CORESTA static ven-

Figure 10.

Ventllation and smoke component deliveries for $13 \%$ ventilated clgarettes (average of 5 determinations). 
Figure 11.

Ventilation for seven clgarette models.

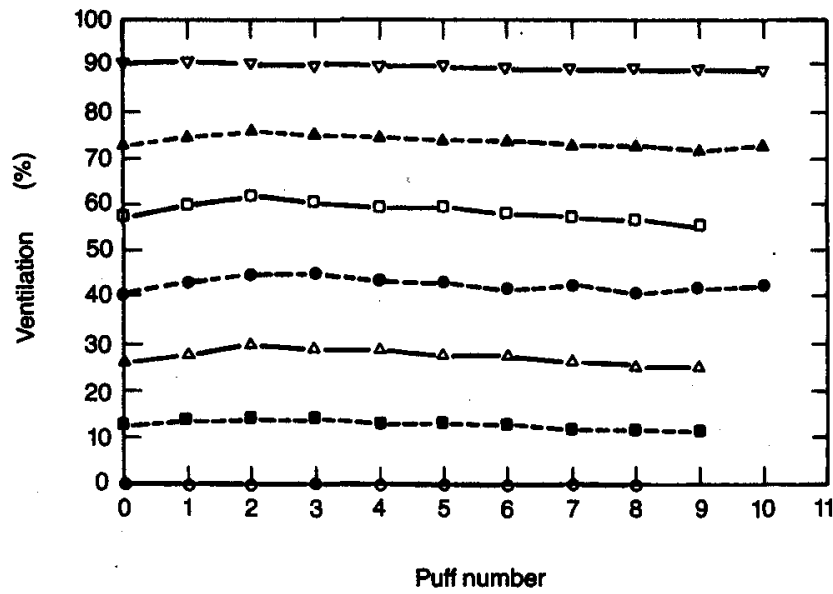

tilation method. The tubes were calibrated and determined to be $22 \%, 53 \%, 74 \%$ and $94 \%$. The CORESTA ventilation method gave results of $22 \%, 52 \%, 73 \%$ and $92 \%$ while the TDL method gave results of $22 \%, 52 \%$, $72 \%$ and $93 \%$. Therefore, with the same calibration tubes, the CORESTA and TDL ventilation methods agreed within $1 \%$ VU which is the same as the accuracy of the CORESTA method.

The averaged results of smoking four $90 \%$ ventilated cigarettes are shown in Figure 8 for ventilation and the smoke component delivery. The smoke delivery was, as would be expected, the lowest of all the cigarettes that were smoked because the ventilation level was the highest for these cigarettes. The smoke delivery was constant for the first seven puffs of all of the $90 \%$ cigarettes with little variation among the individual cigarettes. The ventilation level was nearly constant with only $1 \%$ VU decrease. The variation between the different cigarettes was probably due to a difference in burning characteristics which changed the position at which the individual puffs were taken. Note that the ventilation level increased from puff zero, which was an unlit puff, to the first puff which was the lighting puff. This occurred because of the increase in the pressure drop of the cigarette rod due to the formation of the coal. This increase in pressure drop has been discussed by several researchers including BAKER (19 (also references therein)) and $\mathrm{K}_{\mathrm{ETTH}}(10$ (also references therein)). Lower ventilation levels showed an even greater increase from the unlit to lighting puff, as will be discussed later.

The average results of the ventilation and smoke delivery of four cigarettes smoked with a target ventilation of $40 \%$ are shown in Figure 9. The smoke delivery and the ventilation showed a larger variation than in the $90 \%$ ventilation case. As the cigarette model ventilation levels decreased from the $90 \%$ level, the variation in the measured ventilation values increased for all the ventilation models tested. The smoke delivery presented in Figure 9 showed an immediate increase in the delivery from the first puff, which was different from
Flgure 12.

Smoke component delivery for seven clgarette models.

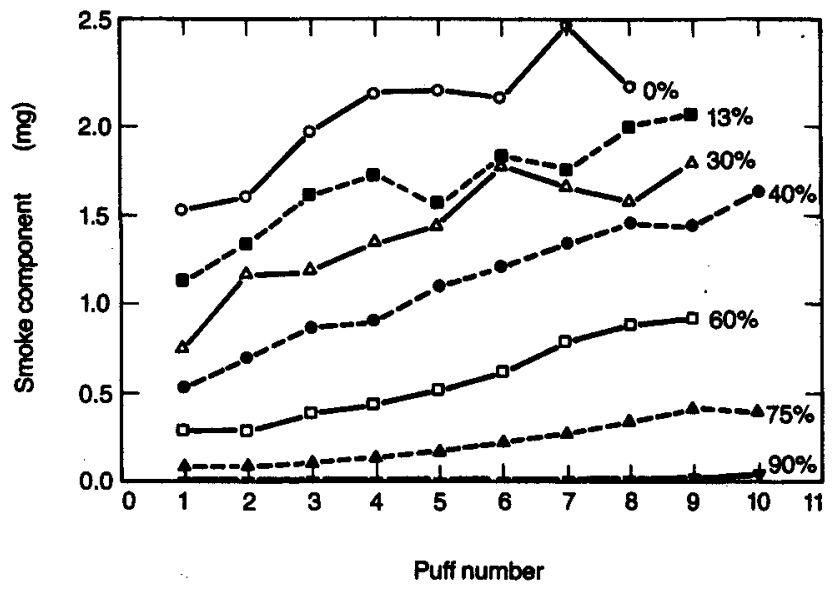

the $90 \%$ ventilation case. The increase in the smoke component delivery was due to substantial changes in the component resident time in the tobacco rod as the coal moves down the tobacco rod. The ventilation for the $40 \%$ model showed the greatest change from the unlit puff to the smoking puff of any of the cigarettes smoked. The maximum in the ventilation occurred for the third puff. From the third puff to the final puff, the ventilation gradually decreased. The ventilation decrease was caused by a decrease in the tobacco rod pressure drop due to the decrease in the tobacco rod length. Since the same volume was pulled into the syringe of the smoking machine, less of the volume was pulled through the ventilation holes and more was pulled through the tobacco rod. Therefore, as the cigarette was smoked the ventilation level decreased.

The averaged results of the ventilation and smoke delivery for five $13 \%$ ventilated cigarettes are shown in Figure 10 . The smoke delivery was similar to the $40 \%$ ventilation case except the delivery values were larger. The experimental ventilation did not have as large an increase from the unlit puff to the lit puffs as did the $40 \%$ model.

The ventilation and smoke component deliveries for all of the cigarette models tested are given in Figures 11 and 12 respectively. As expected the highest smoke delivery was obtained for the non-ventilated model. The smoke delivery decreased from this level as the ventilation increased. The higher variation in the puff-by-puff smoke delivery was evident for the models with the lower ventilation levels. The smoke delivery for the last puff in each of the ventilation cases was calculated from the full delivery of the puff and no partial puffs were considered. These results appeared to be clear and consistent with what one would have expected and while they illustrate the data collected in this experiment, it was obvious that further data analysis was required to provide more in-depth and hopefully beneficial information. Two such analyses are presented which demonstrate the information that these experimental measurements can provide. 
Figure 13.

Smoke component concentration Incident on filter for seven clgarette models.

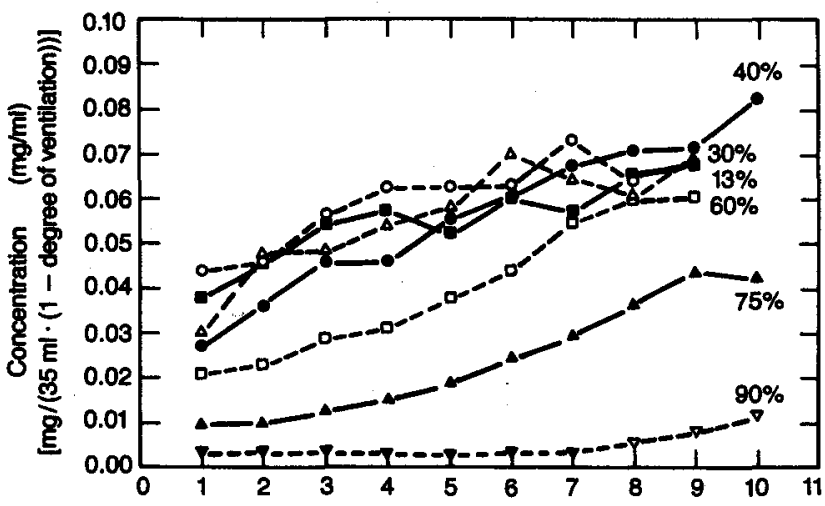

Puti number

It has been known for some time that ventilation alone does not account for the observed reduction in smoke delivery at the higher ventilation levels. To address this phenomenon the smoke component concentration incident on the filter was calculated and the results are shown in Figure 13. The profiles for the $0 \%, 13 \%$, $30 \%$ and $40 \%$ ventilation models all overlapped, which indicated that ventilation accounted for most of the reduction in the smoke component concentration. The $60 \%, 75 \%$ and $90 \%$ ventilation models showed a larger reduction in the smoke component concentration than could be accounted for by ventilation alone. Of course diffusion of this particular gaseous component through the cigarette paper was responsible for much of the observed differences and appeared to play an increasingly important role between $40 \%$ and $60 \%$ ventilation. In addition, for the ventilation levels approaching $100 \%$, the volume of air passing through the cigarette coal was less than or similar to the volume of air in the cigarette rod. Therefore the smoke component concentration was diluted by the air in the free volume of the tobacco rod. Thus, the smoke delivery was reduced even if no diffusion occurred during the puff.

A second example involved the evaluation of the degree of change in the ventilation for each puff. Thus far, only the overall profiles for the different ventilation levels have been discussed. Within each profile it has been observed that the ventilation for the 1st puffs through the 3rd puffs increased relative to the static or unlit puff values. To illustrate this observation more clearly, the unlit or static ventilation values were subtracted from the puff-by-puff ventilation values for all the blended cigarette models and the results are given in Figure 14. The increase in the change in dynamic ventilation was largest for the $40 \%$ model. The smallest change was for the $13 \%$ and $90 \%$ models with the other models falling somewhere in between these two levels. This change in dynamic ventilation was related to the formation of the cigarette coal and the resulting change in resistance to draw. These data also support
Flgure 14.

Change In dynamic ventilation for six clgarette models.

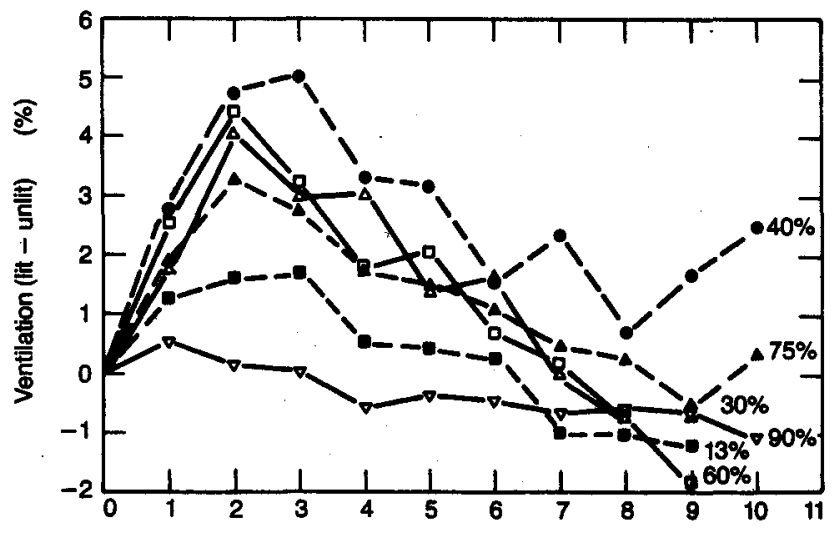

the hypothesis that a puff-by-puff ventilation mathematical model probably would require no change of ventilation at $0 \%$ and $100 \%$ levels, with a maximum change near $50 \%$ ventilation.

A similar hypothesis has been developed independently by MATHIS in his work characterizing the variability behavior of ventilated cigarettes (20). Data were presented which were derived from 2 mathematical model that described the variability of ventilation and pressure drop as functions of cigarette design specifications and the variation of cigarette physical components. The models were verified with experimental measurements using unlit commercial cigarettes ranging in ventilation from $9 \%$ to $88 \%$. It was shown that the standard deviation $\left(s_{D}\right)$ of ventilation due to variability in cigarette design parameters reached a maximum at $50 \%$ ventilation and decreased to zero as the ventilation level approached either $0 \%$ or $100 \%$. The standard deviation $\left(s_{\mathrm{D}}\right)$ maximum was predicted to be $4 \%$ VU. While the MathIs work was performed using unlit cigarettes under static conditions, the present work was performed on cigarettes during smoking (dynamic conditions) and similar trends were observed. As illustrated in Figure 14 the maximum value in the change in ventilation for the 3rd puff of $40 \%$ ventilated cigarettes was $5 \%$ VU. This result obtained under dynamic conditions compared favorably with the $4 \%$ VU predicted by Matris obtained under static conditions. This suggests that the maximum level of variation in ventilation is greatest for $50 \%$ ventilated cigarettes and is similar in magnitude whether the ventilation change is caused by variations in physical parameters and specifications of unlit cigarettes or whether the change is caused by the changing parameters that take place during smoking. The data obtained in experiments such as discussed here provided valuable information for enhancing the accuracy of mathematical ventilation models for predicting the smoke delivery profile as a function of cigarette properties such as filter ventilation, rod dilution, and filter, rod and coal pressure drops, as well as rod 
diffusion. By monitoring simultaneously other parameters, such as resistance to draw, in addition to ventilation and smoke delivery, a more complete and detailed understanding of the effect of filter ventilation on the smoke delivery profile could be obtained.

\section{REFERENCES}

1. Newsome, J. R., C. H. Keith: Variation of the gas phase composition within a burning cigarette; Tob. Sci. 9 (1965) 65-69.

2. Norman, V.: The effect of perforated tipping paper on the yield of various smoke components; Beitr. Tabakforsch. 7 (1974) 282-287.

3. Morie, G. P.: Some factors that affect the diffusion of carbon monoxide out of cigarettes; Tob. Sci. 20 (1976) 174-176.

4. Muramatsu, M., T. Mikami, N. Naitô and H. Tomita: A model study on the diffusion and the dilution of low molecular weight gaseous components through cigarette paper during smoking; Beitr. Tabakforsch. 9 (1977) 141-146.

5. Reynolds, J. F., J. P. Wheeler: Method for the study of air diluted cigarettes; Tob. Sci. 21 (1977) $85-90$.

6. Selke, W. A.: Dilution of cigarette smoke through ventilation of filters; Beitr. Tabakforsch. Int. 9 (1978) 190-192.

7. Selke, W. A., J. H. Mathews: The permeability of cigarette papers and cigarette ventilation; Beitr. $\mathrm{T}_{\mathbf{a}}$ bakforsch. Int. 9 (1978) 193-200.

8. Kiefer, J. E.: Ventilated filters and their effect on smoke composition; Recent Adv. Tob. Sci. 4 (1978) 69-84.

9. Parker, J. A., R. T. Montgomery: Design criteria for ventilated filters; Beitr. Tabakforsch. Int. 10 (1979) $1-6$.

10. Keith, C. H.: The use of pressure drop measurements for estimating ventilation and paper porosity; Beitr. 'Tabakforsch. Int. 10 (1979) 7-16.

11. Browne, C. L., C. H. Keith, R. E. Allen: The effect of filter ventilation on the yield and composition of mainstream and sidestream smokes; Beitr. Tabakforsch. Int. 10 (1980) 81-90.

12. Weatherly, C. H., J. E. Kiefer: Apparatus for measuring cigarette filter ventilation; Tob. Sci, 24 (1980) 105-108.

13. Forrest, G, G. Vilcins: Tunable diode laser measurement of hydrogen cyanide in smoke; Appl. Spectrosc. 34 (1980) 418-419.
14. Vilcins, G., J. O. Lephardt: Aging Processes of cigarette smoke-- Formation of methyl nitrite; Chem. Ind. (Lond.) 22 (1975) 974-975.

15. Schlossberg, H. R., P. L. Kelley: Infrared spectroscopy using tunable lasers; in: Spectrometric techniques, Vol. II, edited by George A. Vanasse, Academic Press, New York, N.Y., 1981, pp. 161-238.

16. Vilcins, G., C. N. Harward, M. E. Parrish, G. T. Forrest: Tunable diode laser applications to cigarette smoke analysis; Proceedings of the Society of Photo-Optical Instrumentation Engineers (SPIE) meeting, 1983, No. 438, 48-54.

17. White, J. U.: Long optical path of large aperture; J. Opt. Soc. Am. 32 (1942) 285-288.

18. CORESTA Recommended Method No. 6: Measurement of ventilation - Definitions and principle of measurement (November 1983); CORESTA Information Bulletin 1983/2-3, pp. 19-30.

19. Baker, R. R.: Contributions to the draw resistance of a burning cigarette; Beitr. Tabakforsch. 8 (1975) 124-131.

20. Mathis, D. E.: Component analysis of pressure drop and ventilation variability; Beitr. Tabakforsch. Int. 12 (1984) 169-177.

\section{Acknowledgements}

The authors wish to thank Jobn Bivins for the construction of the glass ventilation chamber, Trish Sinkiewicz for typing the manuscript, and Jim Day and Chuck Nilles for preparing the illustrations.

The autbors also wish to acknowledge the sustained support given by the management to this research, and special thanks are extended to Dr. M. Häusermann for bis efforts in approving the researcb for publication and presentation at the 1984 CORESTA meeting.

Authors'sddress:

Philip Morris Research Center,

P.O. Box 26583,

Richmond, Virginia, 23261,

U.S.A. 